\title{
Erratum to: Applications of Multicomponent Databases to the Improvement of Steel Processing and Design
}

\author{
A. Costa e Silva ${ }^{1}$ (D)
}

Published online: 1 September 2017

(C) ASM International 2017

Erratum to: J. Phase Equilib. Diffus.

DOI 10.1007/s11669-017-0575-2

The following credit line was missing from the first page of the article:
This article is an expanded version of an invited presentation given at special sessions of the MS\&T meeting held in Salt Lake City, Utah, from October 23-27, 2016. The special sessions were dedicated to honor Dr. Ursula R. Kattner, recipient of the ASM International 2016 J. Willard Gibbs Phase Equilibria Award.

The online version of the original article can be found under doi:10.1007/s11669-017-0575-2.

\footnotetext{
A. Costa e Silva

andre.costaesilva@gmail.com

1 EEIMVR-UFF Volta Redonda, Rio de Janeiro, RJ, Brazil
} 